\title{
Radionuclide concentration in cabbage samples due to gamma radiation in Samsun, Turkey
}

\author{
Aydan Altıkulaç ${ }^{l}$, Hasan Gümüşs ${ }^{2}$ \\ ${ }^{1}$ Muğla Sitkı Koçman University, Ula Ali Koçman MYO, Department of Electricity and Energy, Muğla, Turkey \\ ${ }^{2}$ Ondokuzmayıs University, Faculty of Sciences and Art, Department of Physics, Samsun, Turkey
}

\begin{abstract}
Establishing of radioactivity planes in foodstuff has emphasis because it allows the evaluation of population exposure to radiation by take nourishment. In this paper, the activity concentrations of ${ }^{226} \mathrm{Ra}$, ${ }^{232} \mathrm{Th},{ }^{40} \mathrm{~K}$ and ${ }^{137} \mathrm{Cs}$ were determined in cabbage samples collected from Samsun city of Turkey using a gamma ray spectrometry method with a HPGe detector. The mean concentration value of ${ }^{226} \mathrm{Ra},{ }^{232} \mathrm{Th},{ }^{40} \mathrm{~K}$ and ${ }^{137} \mathrm{Cs}$ in cabbage samples were $1.11 \pm 0.03 \mathrm{Bqkg}^{-1}, 1.44 \pm 0.04 \mathrm{Bqkg}^{-1}, 743.75 \pm 21.21 \mathrm{Bqkg}^{-1}$ and $0.18 \pm 0.003 \mathrm{Bqkg}^{-1}$, respectively. The calculated total annual effective dose received from ${ }^{226} \mathrm{Ra}^{232} \mathrm{Th},{ }^{40} \mathrm{~K}$ and ${ }^{137} \mathrm{Cs}$ due to cabbage samples by population of Samsun province was quite lower than the World average value as suggested by UNSCEAR.
\end{abstract}

\section{Introduction}

The sources of radioactivity in the environment have natural, terrestrial and anthropogenic origins which are resulted from nuclear trial and the processing of nuclear power stations. It is known that air residue of artificial radionuclides be formed as a result of the significant series of nuclear gun tests and nuclear disaster such as the Chernobyl disaster in 1986. The primary resource of artificial radionuclides in Turkey is the nuclear contamination from the Chernobyl accidents. During the process of nuclear waste, the airbone particles may be intercepted by plants or return to help soil. Therefore, plants may get radioactivity nuclides by deposition of radioactive waste on the foodstuff directly and by absorption from the soil Measurement of the concentrations of radionuclides present in foodstuffs permits the determine of the dose caused by the intake of foodstuff [1]. Since gamma radiation provides information about excess lifetime cancer risk, determining gamma dose rate has also importance [2]. The aim of this study is to determine the specific activities of radionuclides such as ${ }^{226} \mathrm{Ra},{ }^{232} \mathrm{Th},{ }^{40} \mathrm{~K}$ and ${ }^{137} \mathrm{Cs}$ in cabbage samples grown in the Samsun city which is so close to the nuclear central that is going to be built in Turkey and calculate the annual effective dose.

\section{Materials and methods}

The samples were put inside on the detector and take counted for a term of $80.000 \mathrm{~s}$. The net area under the specific peaks in energy spectrum was calculated by taking counts owing to Compton scattering of suitable peaks. From the net area of a clear peak, the activity concentrations in the samples were acquired from the following equation.

$$
C\left(B q k g^{-1}\right)=\frac{C n}{\varepsilon P \gamma M S}
$$

Where $\mathrm{C}$ is the activity concentration of the radionuclide in sample given in $\mathrm{Bqkg}^{-1}, \mathrm{C}_{\mathrm{n}}$ is the count ratio under the specific peak, $\mathcal{E}$ is the detector efficiency at the certain $\gamma-$ ray energy, $\mathrm{P}_{\mathrm{y}}$ is the exact progression probability of the specific $\gamma$-ray and $M_{s}$ is the mass of the sample [4]. The energy and efficiency calibration of the detector were performed using photopeaks from radioactive standards IAEA- RGU-1, IAEA-RGTh-1 and IAEA-RGK-1 reference materials [5]. Calibration sources were prepared with the same geometry as the vegetable samples thus didn't need to a geometry correction. The efficiency tables were formed by using known activities of photopeaks of intense gamma emitters from uranium series nuclides, ${ }^{214} \mathrm{Bi}$ and ${ }^{214} \mathrm{~Pb}$, thorium series nuclides ${ }^{228} \mathrm{Ac}$ and ${ }^{208} \mathrm{Tl}$ and gamma transitions of $1461 \mathrm{keV}$ for $\mathrm{K}$ were also used [6]. Relative efficiency at $1332 \mathrm{keV}^{60} \mathrm{Co}$ is $\% 35$. The ${ }^{226} \mathrm{Ra}$ activity of the samples was detected owing to the density of $351.9 \mathrm{keV}$ and $609.3 \mathrm{keV}$ gamma marks of ${ }^{214} \mathrm{~Pb}$ and ${ }^{214} \mathrm{Bi}$ separately.

\section{Result and discussion}

\subsection{Activity concentrations}

The activity concentrations in cabbage samples ranged from $0.38 \pm 0.01$ to $2.7 \pm 0.08$ with an average $1.11 \pm 0.03$ $\mathrm{Bqkg}^{-1}$ for ${ }^{226} \mathrm{Ra}$; from $0.5 \pm 0.01$ to $2.55 \pm 0.08$ with an average $1.44 \pm 0.04 \mathrm{Bqkg}^{-1}$ for ${ }^{232} \mathrm{Th}$; from $0.1 \pm 0.003$ to $0.71 \pm 0.02$ with an average $0.18 \pm 0.003$ for ${ }^{137} \mathrm{Cs}$. The activity concentrations of ${ }^{137} \mathrm{Cs}$ are quite low values in 
many samples. As regarding of ${ }^{40} \mathrm{~K}$, Table. 1 presents its measured activity concentrations in cabbage samples. The activity concentrations of ${ }^{40} \mathrm{~K}$ varied between 373.37 and $1164.87 \pm 36.25$ with an average $743.75 \pm 21.21$. It can be said that the studied radionuclides $\left({ }^{226} \mathrm{Ra},{ }^{232} \mathrm{Th},{ }^{40} \mathrm{~K}\right.$ and ${ }^{137} \mathrm{Cs}$ ) were defined in all cabbage samples.

Table 1. Activity concentrations of ${ }^{226} \mathrm{Ra},{ }^{232} \mathrm{Th},{ }^{40} \mathrm{~K}$ and ${ }^{137} \mathrm{Cs}$ in evaluated in cabbage samples

\begin{tabular}{cllll}
\hline Sample & \multicolumn{4}{l}{ Activity concentrations of cabbage samples } \\
\cline { 2 - 5 } ID & ${ }^{226} \mathrm{Ra}$ & ${ }^{232} \mathrm{Th}$ & ${ }^{40} \mathrm{~K}$ & $\mathrm{Cs}$ \\
\hline 1 & $0.75 \pm 0.02$ & $1.98 \pm 0.05$ & $753.37 \pm 24.87$ & $0.25 \pm 0.008$ \\
2 & $0.62 \pm 0.02$ & $0.7 \pm 0.02$ & $866.75 \pm 27.37$ & $0.16 \pm 0.005$ \\
3 & $1.6 \pm 0.05$ & $1.16 \pm 0.03$ & $1035.5 \pm 32.12$ & $0.22 \pm 0.007$ \\
4 & $0.38 \pm 0.01$ & $0.63 \pm 0.02$ & $940.12 \pm 28.5$ & $0.12 \pm 0.003$ \\
5 & $0.47 \pm 0.01$ & $1.25 \pm 0.03$ & $339.62 \pm 11.87$ & $0.11 \pm 0.003$ \\
6 & $0.26 \pm 0.008$ & $0.57 \pm 0.01$ & $399.37 \pm 12.5$ & $0.1 \pm 0.003$ \\
7 & $1.07 \pm 0.03$ & $2.55 \pm 0.08$ & $1221.5 \pm 39.5$ & $0.27 \pm 0.007$ \\
8 & $0.66 \pm 0.02$ & $2.05 \pm 0.06$ & $1164.87 \pm 36.25$ & $0.71 \pm 0.02$ \\
9 & $1.52 \pm 0.05$ & $6.02 \pm 0.19$ & $915.25 \pm 29.62$ & $0.22 \pm 0.007$ \\
10 & $0.7 \pm 0.02$ & $0.5 \pm 0.01$ & $373.37 \pm 11.72$ & $0.36 \pm 0.01$ \\
11 & $2.7 \pm 0.08$ & $1.72 \pm 0.05$ & $650.25 \pm 21.25$ & $0.20 \pm 0.007$ \\
12 & $0.71 \pm 0.02$ & $1.9 \pm 0.06$ & $883 \pm 28.12$ & $0.25 \pm 0.007$ \\
13 & $1.35 \pm 0.04$ & $0.98 \pm 0.02$ & $440.5 \pm 14.12$ & $0.13 \pm 0.003$ \\
14 & $1.48 \pm 0.04$ & $0.91 \pm 0.02$ & $430.37 \pm 14.37$ & $0.21 \pm 0.007$ \\
Average & $1.11 \pm 0.03$ & $1.44 \pm 0.04$ & $743.75 \pm 21.21$ & $0.18 \pm 0.003$ \\
\hline
\end{tabular}

\subsection{Dose Estimation}

Annual effective dose from estimated to evaluate the threat of radiation for human fitness. Annual effective dose is calculated by

$$
H_{T, r}=\sum\left(U_{\mathrm{I}} C_{r}^{i}\right) g_{T, r}
$$

where $i$ is foodstuff group, $U^{i}$ and $C_{r}^{i}$ are annual consumption ratio $(\mathrm{kg})$ and radionuclide activity concentration $\left(\mathrm{Bqkg}^{-1}\right)$, respectively for their factor, $g_{T, r}$ is dose transformation factor for $r$ radionuclide $\left(\mathrm{SvBq}^{-1}\right)$. Dose transformation factor of ${ }^{226} \mathrm{Ra},{ }^{232} \mathrm{Th},{ }^{40} \mathrm{~K}$ and ${ }^{137} \mathrm{Cs}$ radionuclides for the adult members of society are $4.5 \times 10^{-8}, \quad 2.3 \times 10^{-7}, \quad 6.2 \times 10^{-9}$ and $1.3 \times 10^{-8} \mathrm{SvBq}^{-1}$, respectively $[7,8,9]$. The annual effective dose due to each radionuclide is shown in Table 2 . It can be seen from Table 2 that ${ }^{40} \mathrm{~K}$ conduced the maximum to the annual dose generated by intake of foodstuff. The sum of ${ }^{40} \mathrm{~K}$ doses ensured by foodstuff adds to mean value of $33.66 \pm 0.5 \mu \mathrm{Svy}^{-1}$, which shows the mean annual effective dose for the Turkish consumer.

Table 2. Dose coefficients and appointed effective dose values

\begin{tabular}{|c|c|c|c|c|}
\hline \multirow[t]{2}{*}{ Radioisotopes } & \multirow[t]{2}{*}{$\begin{array}{l}\text { Activity } \\
\text { intake (Bq) }\end{array}$} & \multirow[t]{2}{*}{$\begin{array}{l}\text { AED } \\
\left(\mu \mathrm{SvBq}^{1}\right)\end{array}$} & \multicolumn{2}{|c|}{$\begin{array}{l}\text { Appointed effective dose } \\
\left(\mu \text { Svy }^{-1}\right)\end{array}$} \\
\hline & & & Range $\quad A$ & Average \\
\hline${ }^{226} \mathrm{Ra}$ & $8.10 \pm 0.21$ & 0.045 & $\begin{array}{l}0.08 \pm 0.01- \\
0.52 \pm 0.12\end{array}$ & $0.36 \pm 0.08$ \\
\hline${ }^{232} \mathrm{Th}$ & $10.51 \pm 0.29$ & 0.23 & $\begin{array}{l}1.02 \pm 0.3- \\
12.30 \pm 1.14\end{array}$ & $2.94 \pm 0.61$ \\
\hline${ }^{40} \mathrm{~K}$ & $5.429 \pm 147.53$ & $6.2 \times 10^{-3}$ & $\begin{array}{l}15.37 \pm 0.53- \\
55.28 \pm 1.78\end{array}$ & $33.66 \pm 0.5$ \\
\hline${ }^{137} \mathrm{Cs}$ & $1.31 \pm 0.02$ & $1.3 \times 10^{-2}$ & $\begin{array}{l}0.002 \pm 0.01- \\
0.71 \pm 0.26\end{array}$ & $0.01 \pm 0.003$ \\
\hline
\end{tabular}

The calculated total annual effective dose (AED) received from ${ }^{137} \mathrm{Cs}$ vary from $0.002 \pm 0.01$ to $0.71 \pm 0.26$ with a mean of $0.01 \pm 0.003 \mu \mathrm{Svy}^{-1}$. This paper based on that humans living in Samsun province be exposed radiation dose nearly $38 \mu_{S_{v y}}{ }^{-1}$ from cabbage consumption is quite lower than the World average value $\left(290 \mu \mathrm{Svy}^{-1}\right)$ that established by UNSCEAR [10].

\section{Conclusion}

It was observed that the mean annual effective dose due to ${ }^{40} \mathrm{~K}$ quite higher than ${ }^{137} \mathrm{Cs}$. The total annual effective dose due to consumption of foodstuff was less than the average world value that announced as $290 \mu \mathrm{Svy}^{-1}$ by UNSCEAR. As a result, the study showed that there is no radiological risk for the people living in Samsun province.

\section{References}

1. R. Keser, K.F. Görür, N. Akçay, J.Sci Food Agric, 91, 987-991(2011).

2. Ş.Turhan, K. Abdullah, A. Varınlıoglu, Isotopes in Environmental and Health Studies, 43, 249-256 (2007).

3. D. Mascanzoni, J. Radioanal. Nucl. Chem., 249, 245-249 (2001).

4. S. Yoshida, Y. Muramatsu, J. Environ. Radioact., 41, 183-205 (1998).

5. C. Canbazoğlu, M. Dogru, J. Radioanal Nucl. Chem. 295,1245-1249 (2013).

6. A. Parmaksız, Y. Ağuş, Radiaiton Effects and Defects in Solids, (2014).

7. C. Kuwahara, et al., Sci. Total Environ., 345, 165173 (2005).

8. G. Kirchner, O. Daillant, Sci. Total Environ., 222, 63-70 (1998).

9. M.I. Gasso, et al., Radiat. Protect. Dosim., 87, 213216 (2000). 